\title{
A novel method of ultra-low contrast administration for coronarography and percutaneous coronary intervention using the automatic injector. The need to focus on contrast preservation techniques
}

Nowa metoda minimalizowania dawki kontrastu w przezskórnych zabiegach wieńcowych z użyciem automatycznego iniektora. Konieczność używania technik minimalizujących zużycie środków kontrastowych

\author{
Adam T. Stys ${ }^{1}$, Tomasz Stys ${ }^{1}$, Przemysław Recki ${ }^{2}$ \\ 1Sanford Cardiovascular Institute, University of South Dakota Sanford School of Medicine, Sioux Falls, SD, USA \\ 2Medical University of Warsaw, Poland
}

Post Kardiol Interw 2011; 7, 1 (23): 8-14 DOI: $10.5114 /$ pwki.2011.21186

\begin{abstract}
Background: Contrast-induced nephropathy $(\mathrm{CIN})$ is becoming a more pertinent issue in coronary percutaneous procedures, as the population at risk grows. Contrast preservation is the first and probably most important step in prevention of CIN, and yet the research focus seems to be on CIN preventing drugs.

Aim: We describe a novel method of contrast preservation for coronarography and percutaneous coronary intervention $(\mathrm{PCl})$ based on use of the automatic contrast injector $(\mathrm{ACl})$. The method also uses a standardized approach to catheterization aimed at minimizing contrast load; however, it is the programming of the $\mathrm{ACl}$ that allows for the ultralow contrast dose. We present two cases to illustrate the technique.

Material and methods: We have used this standardized protocol successfully for the last 4 years in our cath lab in patients with increased risk of CIN, consistently achieving $10 \mathrm{ml}$ or less of contrast load per coronary case. Our ACI programming protocol is relatively easy to follow.

Results and conclusions: We think that use of $\mathrm{ACl}$ with appropriate programming should become a preferred, if not standard approach in patients at increased CIN risk. We believe that refocusing on contrast preservation techniques and their distribution throughout the interventional community is of utmost importance for public health.
\end{abstract}

Key words: contrast-induced nephropathy, automatic contrast injector

\section{Streszczenie}

Wstęp: Liczba pacjentów ze zwiększonym ryzykiem nefropatii kontrastowej (CIN) po zabiegach przezskórnych na sercu wzrasta. Pomimo że zmniejszenie ilości podanego środka kontrastowego jest najważniejszym ogniwem w profilaktyce tego powikłania, to literatura na ten temat wydaje się nieproporcjonalnie skąpa.

Cel: Opis nowej metody minimalizacji ilości podanego środka kontrastowego w koronarografii i angioplastyce naczyń wieńcowych, opartej głównie na użyciu automatycznego podajnika kontrastu (ACl). Ustandaryzowane podejście do gospodarki kontrastem w czasie zabiegu pozwala na stosowanie minimalnych dawek. W celu pełniejszego zaprezentowania metody opisano 2 typowe przypadki z jej zastosowaniem. 
Materiał i metody: Autorzy stosują zaprezentowane standardowe postępowanie od 4 lat u wszystkich pacjentów ze zwiększonym ryzykiem CIN, skutecznie przeprowadzając zabiegi z użyciem średnio do $10 \mathrm{ml}$ środka kontrastowego. Opisany schemat programowania $\mathrm{ACl}$ jest stosunkowo prosty.

Wyniki i wnioski: Używanie ACl z właściwym programowaniem iniekcji powinno być preferowanym postępowaniem w zabiegach na naczyniach wieńcowych z użyciem środka kontrastowego u pacjentów ze zwiększonym ryzykiem CIN. Zauważamy potrzebę ponownego skupienia się na metodach minimalizacji ilości podanego środka kontrastowego i rozpowszechnienia tych metod wśród kardiologów, co może mieć znaczny i pozytywny wpływ na pacjentów.

Słowa kluczowe: nefropatia kontrastowa, automatyczny iniektor do środków kontrastowych

\section{Introduction}

The amount of administered intravascular contrast for invasive cardiac procedures corresponds to the risk of contrast-induced renal insufficiency (CIN) in multiple studies [1-4]. There has been considerable research towards prevention of $\mathrm{CIN}$, though surprisingly contrast preservation studies seem to be relatively underrepresented in the literature. We would like to describe a protocol developed in our cath lab for coronary angiography and $\mathrm{PCl}$ in patients who are at higher risk of CIN. This protocol has been used by us since 2006 and has been designed for ultra-low contrast dosing with help of the automatic coronary injector (ACI). It has provided a basis for a reliably ultralow dose of contrast administration per patient in our cath lab (often less than $10 \mathrm{ml}$ per case). We present two cases to illustrate our protocol.

\section{Method description \\ General approach}

In patients with renal insufficiency we perform the procedures mostly via femoral access, as ultra-low administration of contrast seems to be easier to achieve in this setting. We often use long sheaths $(35 \mathrm{~cm}$ or even longer), especially in percutaneous coronary intervention (PCI) cases, which translates into easier catheter manipulations and, in our experience, contrast savings. Biplane imaging is always used in cases of increased risk of CIN.

The initial assessment requires choice of catheters based on patients' size, age, sex, and prior catheterization data. If applicable, prior angiography films are reviewed for catheter choices, including films obtained at other institutions. If there is a known proximal chronic total coronary occlusion in the past study, we usually do not inject this artery. In all cases we use low osmolar non-ionic contrast (iodixanol).

\section{Catheter choice}

In cases of coronary angiography, for the left coronary system, we use a $5 \mathrm{Fr} \mathrm{JL} 4.0$ curve for medium and large sized individuals (height over $155 \mathrm{~cm}$ ), and a $5 \mathrm{FrJL} 3.5$ catheter for smaller individuals. For very small frame patients (weight below $45 \mathrm{~kg}$, especially elderly females) we start with a $4 \mathrm{Fr} J \mathrm{~L} 3.5$ catheter. For the RCA, we routinely use $4 \mathrm{Fr}$ 3DRC catheters, except for very large patients (weight over $130 \mathrm{~kg}$, then a $5 \mathrm{Fr}$ 3DRC catheter is used first). Most coronary angiograms can be performed using these catheters. For diagnostic catheterization, catheter sizes over $5 \mathrm{Fr}$ are very rarely required. If the left coronary cannot be engaged with the JL 4.0 catheter, then the choice of the next catheter depends on the anatomy defined by control cineography with the injection as close to the ostium as possible (not more than 2 cc of contrast at flow of 3-5 ml/sec, $0.5 \mathrm{sec}$ rise time). Typically larger or smaller JL curves and Amplatz curves are used then. Likewise, if the 3DRC catheter does not fit the RCA, then usually JR 4.0, multipurpose, or Amplatz curves are used.

In patients with a history of coronary artery bypass grafting the vein grafts are initially approached with a JR 4.0 $5 \mathrm{Fr}$ catheter, then if not successful a bypass left catheter (left system grafts) or multipurpose catheter (RCA grafts) is tried. The internal mammary artery (IMA) is engaged with a $4 \mathrm{Fr}$ IMA catheter. We have not encountered so far a case where a catheter larger than $4 \mathrm{Fr}$ was needed for adequate opacification of the IMA.

\section{Ostium engagement}

Coronary ostium catheter engagement is a crucial step in contrast preservation. Attempts at coronary ostium catheter engagement often involve injection of a significant amount of contrast in the proximity of the ostium. We try to engage the ostia without applying any contrast, carefully watching the pressure wave on the catheter. The typical "jump" of classical coronary catheters as they enter the coronary ostia is anticipated. Once it is seen, then filling of the catheter with contrast is carefully done. The filing of the catheter is done knowing that its volume, on average, is about $2 \mathrm{ml}$. Settings of $2 \mathrm{ml}$, at $2 \mathrm{ml} / \mathrm{sec}, 0.2 \mathrm{sec}$ rise time, and 300 psi, are routinely used. The "spill over" (should amount to about $0.5-1 \mathrm{ml}$ of contrast) provides information for the initial automatic injector settings.

\section{Automatic coronary injector programming}

An automatic coronary injector (ACIST Medical Systems, Eden Prarie, $\mathrm{MN}$ ) is used in all cases. It can be very precisely programmed by setting the volume of contrast per injection, flow, injection pressure, and rise time. Changing these settings dynamically during angiography is the basis 


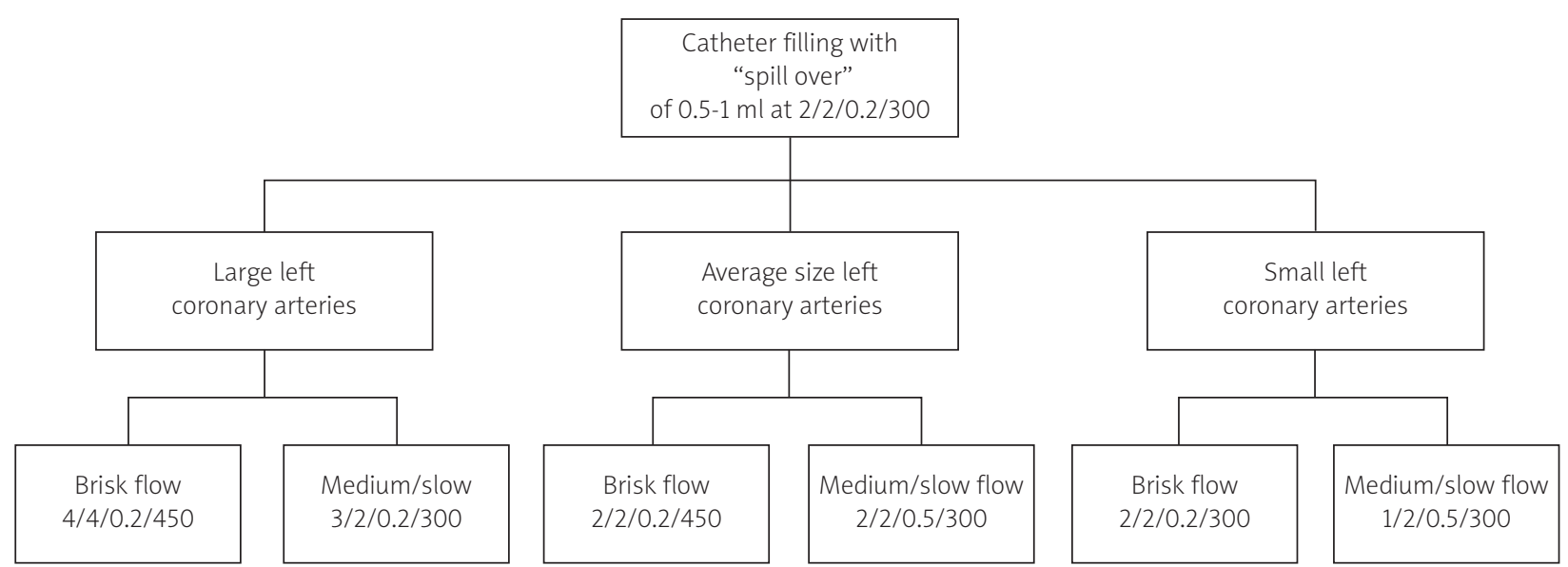

Fig. 1. Left coronary angiography $\mathrm{ACl}$ programming protocol (first injection). The first angiographic run settings depend on the visualization of the coronary upon filling the catheter with contrast. The settings are listed in the following order: volume $(\mathrm{ml}) / \mathrm{flow}(\mathrm{ml} / \mathrm{sec}) /$ rise time $(\mathrm{sec}) / \mathrm{pressure}(\mathrm{psi})$

Ryc. 1. Schemat programowania automatycznego iniektora (ACI) dla pierwszej iniekcji kontrastu do lewej tętnicy wieńcowej. Zaprogramowanie jest zależne od stopnia uwidocznienia tętnicy podczas napetniania cewnika kontrastem. Programowane parametry są podane w następującej kolejności: objętość iniekcji (ml)/przeptyw (ml/s)/czas wzrostu ciśnienia injekcji (s)/ciśnienie maksymalne iniekcji (psi)

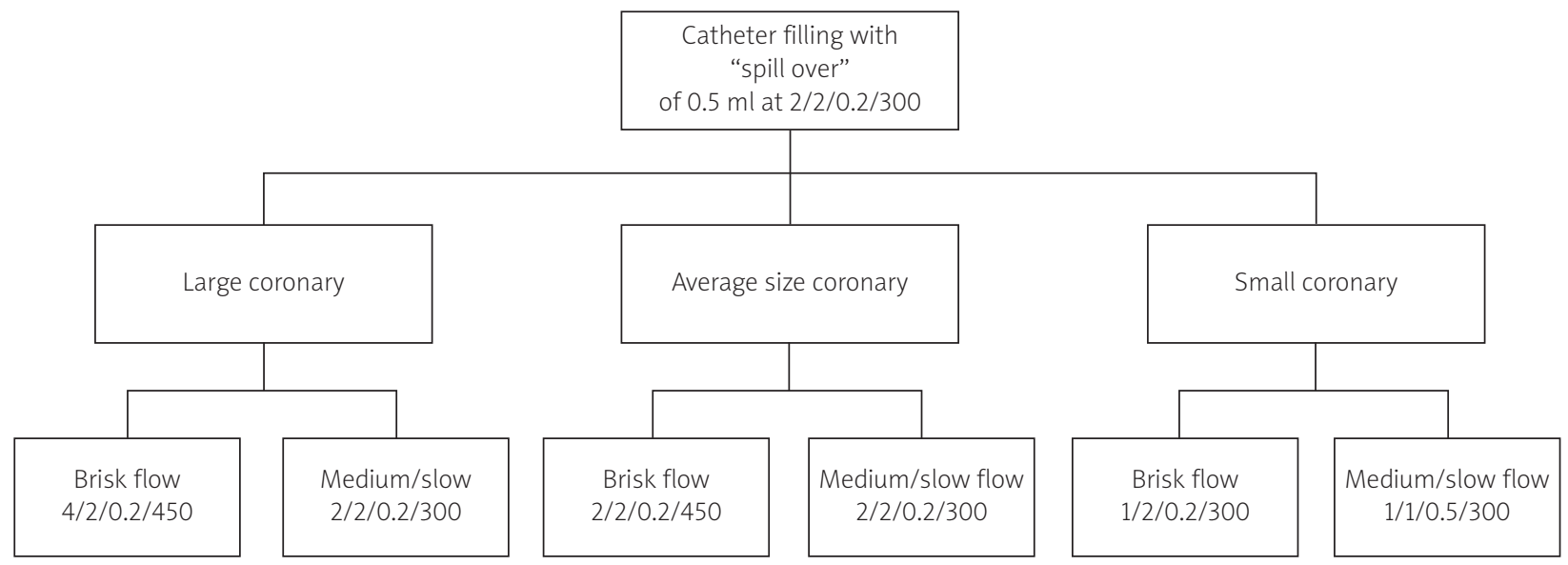

Fig. 2. RCA injections $\mathrm{ACl}$ programming protocol. The settings are listed in the following order: volume $(\mathrm{ml}) /$ flow $(\mathrm{ml} / \mathrm{sec}) /$ rise time $(\mathrm{sec}) /$ pressure $(\mathrm{psi})$

Ryc. 2. Schemat programowania ACl dla prawej tętnicy wieńcowej (RCA). Programowane parametry sa podane w następującej kolejności: objętość iniekcji (ml)/przeptyw (ml/s)/czas wzrostu ciśnienia iniekcji (s)/ciśnienie maksymalne iniekcji (psi)

for the minimization of contrast, without sacrificing the angiographic quality (fig. 1, 2).

Left coronary injection is obtained first in classical RAO caudal and LAO caudal (biplane) views. The information from filling of the catheter with contrast is used for setting the first set of $\mathrm{ACl}$ parameters. Typically, no more than $2 \mathrm{ml}$ of contrast at $2 \mathrm{ml} / \mathrm{sec}$ is used for this injection, unless a very brisk flow in a large coronary system is noted. While this is a "scout" injection of the left system, it usually gives adequate information about the proximal parts of the left system, which these views are geared for. The next injection, in LAO and RAO cranial views, is set up usually with more volume (3-4 $\mathrm{ml})$ as they give information on the more distal parts of the left system. The volume, flow and pressure settings are adjusted using the information from the first injection, i.e. if the coronary flow is brisk, then flow and/or pressure is increased (preferentially over the volume). Usually, these 4 views are sufficient (2 injections) for full assessment of the left coronary system.

The first RCA injection is also usually done with $2 \mathrm{ml}$ of contrast at $2 \mathrm{ml} / \mathrm{sec}, 0.2 \mathrm{sec}$ rise time, and pressure of 
300 psi, unless the catheter filling shows higher than usual flow in the RCA, then we preferentially increase the flow and pressure over the volume. Straight LAO and cranial RAO biplane settings usually make one injection sufficient for RCA angiography. For high coronary flow cases the right amount of pressure and flow is sufficient to get the angiographic information even with $2 \mathrm{ml}$ injection, especially if one examines the cine loop on a frame-byframe basis. A maximum of $600 \mathrm{psi}$ and rate up to $6 \mathrm{ml} / \mathrm{sec}$ are the usual safety limits we observe. We very rarely exceed $5 \mathrm{ml}$ of contrast per injection.

The vein grafts are injected initially at $2 \mathrm{ml} / \mathrm{sec}$ for a total of $2 \mathrm{ml}, 0.2 \mathrm{sec}$ rise time, and 300 psi. Rarely higher settings are required for these and often flow rates as low as $1 \mathrm{ml} / \mathrm{sec}$ and total volume of $1 \mathrm{ml}$ are sufficient.

The internal mammary artery injections are usually $2 \mathrm{ml}$ total volume at $2 \mathrm{ml} / \mathrm{sec}, 0.2 \mathrm{sec}$ rise time and $300 \mathrm{psi}$. Careful set up of the biplane cameras is necessary to be able to pan across the whole IMA and its grafted territory in both planes.

We routinely measure the left ventricular end-diastolic pressure in patients at increased risk for CIN, which gives us guidance on the hydration status. We act on this measurement while the patient is in the cath lab (more hydration or intravenous diuretic) and believe that this likely decreases the risk of CIN further.

\section{Percutaneous coronary intervention}

As usual, for $\mathrm{PCl}$ the choice of guide catheters depends on the angiography data. In general, more aggressive guides

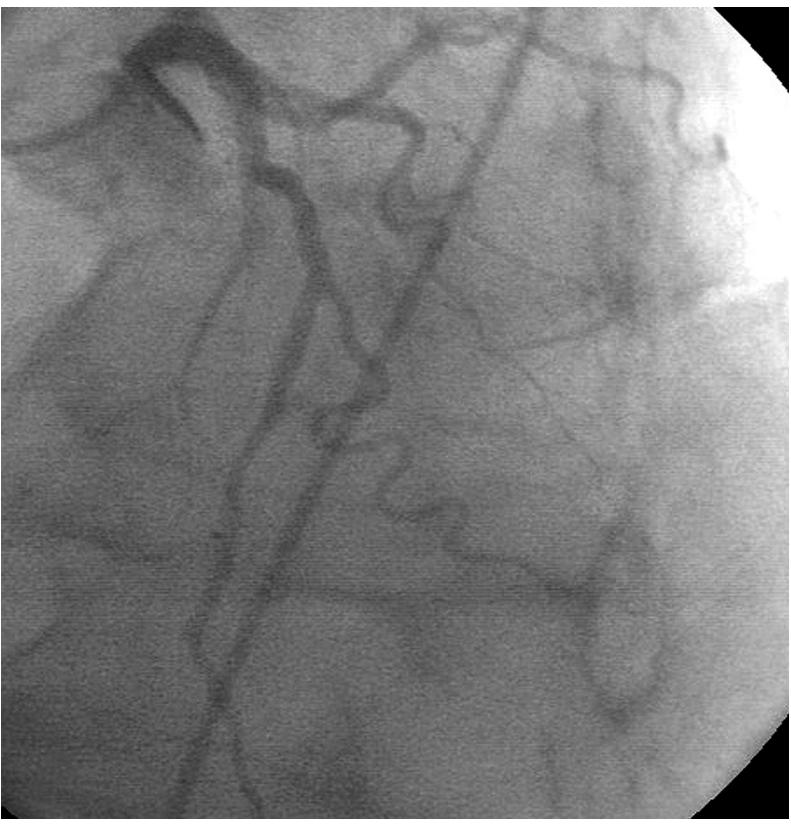

Fig. 3. Left coronary injection with $2 \mathrm{ml}$ of contrast at $2 \mathrm{ml} / \mathrm{sec}, 0.2 \mathrm{sec}$ rise time, $300 \mathrm{psi}$

Ryc. 3. Iniekcja lewej tętnicy wieńcowej z użyciem $2 \mathrm{ml}$ kontrastu, przy przepływie $2 \mathrm{ml} / \mathrm{s}$, czasem wzrostu ciśnienia 0,2 s i ciśnieniem 300 psi are used, as better support shortens the procedure, thus at least potentially decreasing contrast load. Also, with deeper sitting of guide catheters less contrast volume per injection is required. Thus, commonly EBU curves for the left and Amplatz curves for the RCA are used. Usually 6 Fr guides are used, unless a very simple $\mathrm{PCl}$ is anticipated, then a $5 \mathrm{Fr}$ system is chosen. The $\mathrm{PCl}$ is done with contrast rate of administration and rate of rise low enough to minimize "back flow" of contrast into the aorta. Usually, $2 \mathrm{ml}$ volume, $2 \mathrm{ml} / \mathrm{sec}$ flow and $0.2 \mathrm{sec}$ rise time at 300-600 psi are sufficient. The guide wire and balloon/stent catheters inserted into the coronary centralize the guide tip, allowing for more efficient injections. For this reason, we avoid coronary injections through the guide catheter without at least partial guide wire insertion into the coronary artery. The guide wire passage is usually done without contrast, with the help of a memorized diagnostic angiogram, bony landmarks, as well as using coronary calcifications as a guide. The guide wire tip behaviour provides important information on its position. Most of the injections are recorded as cinegraphy runs, as they can be analysed, if necessary, beat by beat for further contrast savings.

\section{Case studies}

\section{Case 1}

An 84-year-old male with worsening heart failure and abnormal myocardial perfusion scan came for scheduled coronary angiography. The patient's height was $175 \mathrm{~cm}$ and weight was $86.2 \mathrm{~kg}$. Baseline creatinine clearance was

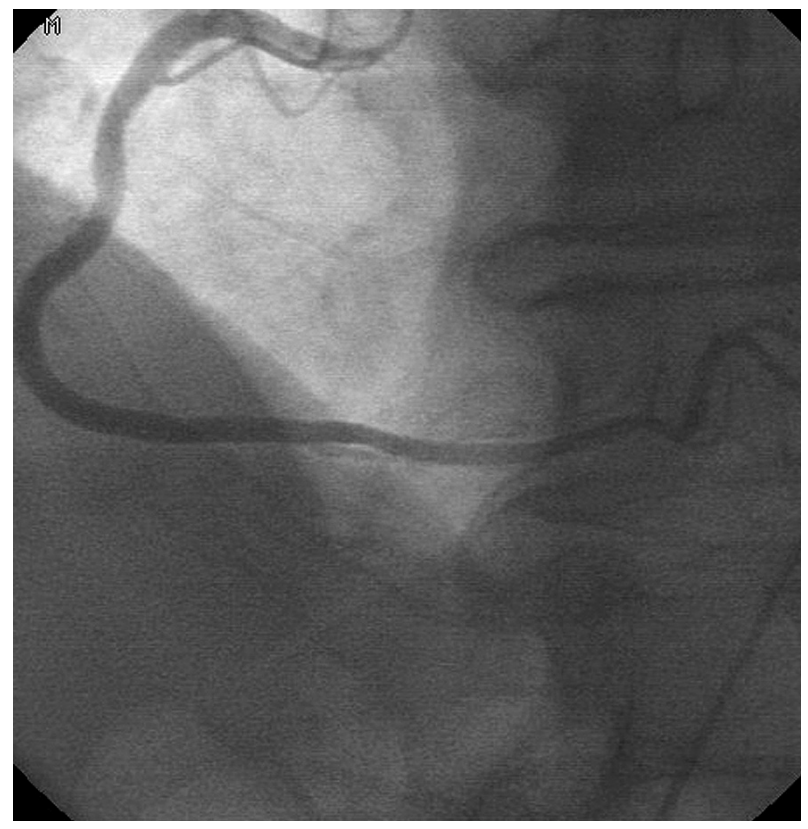

Fig. 4. RCA injection with $2 \mathrm{ml}$ of contrast at $2 \mathrm{ml} / \mathrm{sec}, 0.2 \mathrm{sec}$ rise time, $300 \mathrm{psi}$

Ryc. 4. Iniekcja RCA z użyciem 2 ml kontrastu, przy przeptywie $2 \mathrm{ml} / \mathrm{s}$, czasem wzrostu ciśnienia 0,2 s i ciśnieniem 300 psi 
$47 \mathrm{ml} / \mathrm{min}$ (creatinine of $1.43 \mathrm{mg} / \mathrm{dl}$ ). The patient was pre-medicated with sodium bicarbonate infusion and $\mathrm{N}$-acetylcysteine. A $5 \mathrm{Fr} 35 \mathrm{~cm}$ long sheath was inserted into the right femoral artery. A JL 4.0 $5 \mathrm{Fr}$ diagnostic catheter was used for the left coronary angiography as described above. A 3DRC 4 Fr catheter was used for the RCA. Two left system injections (4 cine runs, biplane) were done with $2 \mathrm{ml}$ volume, at $2 \mathrm{ml} / \mathrm{sec}$ with $0.2 \mathrm{sec}$ rise time (fig. 3). One RCA injection (2 runs) was done with the same parameters as for the left system (fig. 4). A total of $8 \mathrm{ml}$ of contrast was used for the whole procedure $(4 \mathrm{ml}$ for left, $2 \mathrm{ml}$ for right coronary and $1 \mathrm{ml}$ for catheter filling/spill over for each). Coronary angiograms have shown non-obstructive disease in RCA and distal significant disease in the left anterior descending artery (LAD). The creatinine clearance was $48 \mathrm{ml} / \mathrm{min}$ (creatinine of $1.40 \mathrm{mg} / \mathrm{dl}$ ) one day after the procedure and $48 \mathrm{ml} / \mathrm{min}$ (creatinine of $1.4 \mathrm{mg} / \mathrm{dl}$ ) 7 days after the procedure.

\section{Case 2}

An 88-year-old male presented for elective $\mathrm{PCl}$ of total chronic RCA in stent occlusion (fig. 5). The patient's height was $180 \mathrm{~cm}$ and weight was $83.5 \mathrm{~kg}$. Baseline creatinine



Fig. 5. RCA injection. ACl settings: $1 \mathrm{ml}$ of contrast at $1 \mathrm{ml} / \mathrm{sec}, 0.2 \mathrm{sec}$ rise time, $300 \mathrm{psi}$. The AL guide catheter is deeply engaged. RCA is totally occluded in the mid section. The guide wire has been negotiated through the total chronic occlusion in the mid RCA

Ryc. 5. Iniekcja RCA z użyciem $1 \mathrm{ml}$ kontrastu, przy przeptywie $1 \mathrm{ml} / \mathrm{s}$, czasem wzrostu ciśnienia 0,2 s i ciśnieniem 300 psi. Cewnik matka typu AL pozwala na głęboka intubację tętnicy. Tętnica jest zamknięta totalnie w środkowym odcinku. Koniec prowadnika jest widoczny w gatęzi dystalnej tętnicy clearance was $36 \mathrm{ml} / \mathrm{min}$ (creatinine of $1.66 \mathrm{mg} / \mathrm{dl}$ ). Three weeks before, he had undergone complex LAD stenting in the setting of non-ST elevation myocardial infarction. A $6 \mathrm{Fr} 35 \mathrm{~cm}$ sheath was inserted into the right femoral artery. A 6 Fr AL 0.75 guide catheter was used to engage the RCA ostium and initially a BMW guide wire was tried unsuccessfully to cross the occlusion, relying mostly on the calcium print of the artery. Then a Pilot 50 wire was used successfully to cross the lesion. The deep intubation of the RCA with the guide catheter allowed for the $1 \mathrm{ml} / \mathrm{sec}, 1 \mathrm{ml}$ total volume, $0.2 \mathrm{sec}$ rise time (600 psi) injections that were diagnostic. After multiple pre-dilations with a $2.0 \times 30 \mathrm{~mm}$ balloon in the distal, mid, and proximal RCA, stenting was done with two $2.5 \times 28 \mathrm{~mm}$ Xience $V$ stents starting distally, then $3.0 \times 28 \mathrm{~mm}$ and $3.0 \times 23 \mathrm{~mm}$ Xience $V$ stents up to the proximal vessel. A good result was obtained (fig. 6, 7). A total of $9 \mathrm{ml}$ of contrast was used for the procedure. The creatinine clearance was $41 \mathrm{ml} / \mathrm{min}$ (creatinine of $1.48 \mathrm{mg} / \mathrm{dl}$ ) one day after the procedure and $38 \mathrm{ml} / \mathrm{min}$ (creatinine of $1.6 \mathrm{mg} / \mathrm{dl}) 7$ days after the procedure.

\section{Discussion}

Contrast minimization is becoming a greater necessity as the patient population for invasive cardiac procedures becomes older and more complex, and thus at higher risk

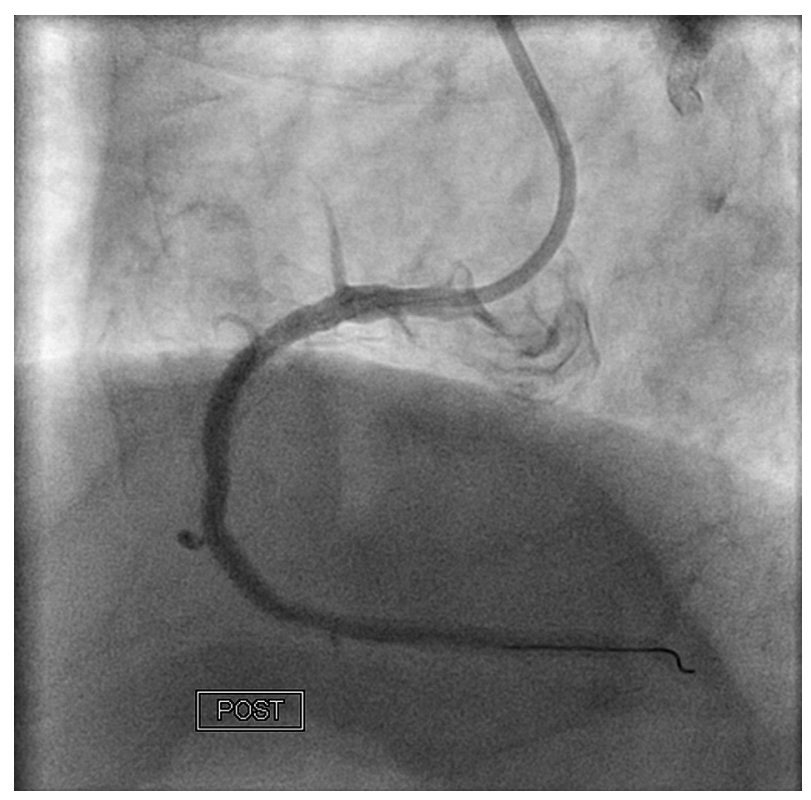

Fig. 6. RCA injection. ACl settings: $1 \mathrm{ml}$ of contrast at $1 \mathrm{ml} / \mathrm{sec}, 0.2 \mathrm{sec}$ rise time, $300 \mathrm{psi}$. The AL guide catheter is deeply engaged; this is an early frame showing proximal to distal RCA, but contrast has not reached its branches yet

Ryc. 6. Iniekcja RCA z użyciem $1 \mathrm{ml}$ kontrastu, przy przeptywie $1 \mathrm{ml} / \mathrm{s}$, czasem wzrostu ciśnienia 0,2 s i ciśnieniem 300 psi. Cewnik matka typu AL pozwala na gtęboka intubację tętnicy. Początek iniekcji - kontrast jeszcze nie dotarł do końcowych gatęzi tętnicy 
of CIN. Also, decreased contrast use should save money. The most effective, so far, pharmacological method of prevention of CIN tested in larger populations is hydration with sodium bicarbonate and $\mathrm{N}$-acetylcysteine administration [5]. This method and others are not very robust in decreasing CIN. Contrast preservation is the first and probably most important step in reducing CIN.

Our method is based on carefully following the protocol, designed for a biplane lab and based on the use of ACl. The $\mathrm{ACl}$ settings are based on the preferential use of higher flow and pressure over the volume of contrast per injection. In our experience, the accurately programmed flow and pressure settings for a bolus of contrast are more important than the absolute volume. With the right settings of the $\mathrm{ACl}$, one can literally follow the contrast bolus frame by frame on review of films, achieving the full diagnostic potential (fig. 6, 7).

A recent publication described manual injections of ultra-low contrast volumes for coronary procedures [6]. We have been applying some of the techniques described in this report; however, we do not use intravascular ultrasound routinely, as a contrast saving tool. In our experience, the addition of $\mathrm{ACl}$ to our protocol drastically saves on the contrast volume to the point that contrast exposure might possibly become a negligible risk when it comes to CIN. Importantly, automatic injections also decrease the uncertainty factor, in view of the individual variations in dynamics of manual contrast administration (both intra- and inter-operator). Standardized injections by $\mathrm{ACl}$ are easier to introduce and teach throughout the cardiology community for the benefit of our patients.

Automatic injectors have been shown to improve the quality of angiography through smaller catheters (i.e. $4 \mathrm{Fr}$ ) and reduce patient contrast dose and fluoroscopy time [7, 8]. They allow for monitoring of pressure at the catheter tip and have the inbuilt safety feature of response to the intensity of the operator's pressure on the control handle. Thus, $\mathrm{ACl}$ use could be safer and could improve image quality, in addition to saving on the contrast volume, compared to manual injections [9].

The choice of catheters depending on patient characteristics has helped us minimize contrast volume. The smaller the internal lumen of the catheter, the less contrast one might expect to use per injection. However, in larger individuals, requiring higher rates and volumes of administration, $4 \mathrm{Fr}$ catheters for the left coronary artery might be impractical, as they will have a tendency to prolapse out of the coronary with the pressure delivered and also their use might not achieve full opacification.

The learning curve for our protocol is not steep, the biggest challenge being the cannulation of coronary ostia with a minimal amount or without contrast. Achieving coaxial alignment of the catheter in the coronary also



Fig. 7. RCA injection. $\mathrm{ACl}$ settings: $1 \mathrm{ml}$ of contrast at $1 \mathrm{ml} / \mathrm{sec}, 0.2 \mathrm{sec}$ rise time, $300 \mathrm{psi}$. The contrast has reached the distal RCA branches

Ryc. 7. Iniekcja RCA z użyciem $1 \mathrm{ml}$ kontrastu, przy przeptywie $1 \mathrm{ml} / \mathrm{s}$, czasem wzrostu ciśnienia 0,2 s i ciśnieniem 300 psi. Kontrast dotart do końcowych gatęzi tętnicy

helps in contrast preservation. Coronary ostium engagement is the most operator-dependent step; however, these techniques are taught in every cardiology fellowship. The individual further adjustments of the injection parameters after the initial injection also require some experience; however, they are quite intuitive, and thus easy to master.

\section{Conclusions}

Intravascular contrast administration using our $\mathrm{ACl}$ protocol allows for ultra-low volumes of contrast per coronary case, aimed at reducing the risk of CIN. The protocol standardization makes it easy to teach and disseminate through the cardiology community. We think that the use of appropriately programmed $\mathrm{ACl}$ is essential in reducing contrast load for coronary percutaneous procedures. We believe that it is high time to go back to the basics and focus more on contrast preservation techniques, rather than chase the so far elusive goal of ideal CIN protective medication(s).

\section{References}

1. Mehran R, Aymong ED, Nikolsky E, et al. A simple risk score for prediction of contrast-induced nephropathy after percutaneous coronary intervention: Development and initial validation. J Am Coll Cardiol 2004; 44: 1393-1399.

2. Dangas G, lakovu I, Nikolsky E, et al. Contrast-induced nephropathy after percutaneous coronary interventions in relation to chronic 
kidney disease and hemodynamic variables. Am J Coll Cardiol 2005; 95: 13-19.

3. Weisbord SD, Mor MK, Resnik, MA, et al. Prevention, incidence, and outcomes of contrast-induced acute kidney injury. Arch Intern Med 2008; 168: 1325-1332.

4. Kane GC, Doyle BJ, Lerman A, et al. Ultra-low contrast volumes reduce rates of contrast-induced nephropathy in patients with chronic kidney disease undergoing coronary angiography. J Am Coll Cardiol 2008; 51: 89-92

5. Brown JR, Block CA, Malenka DJ, et al. Sodium Bicarbonate plus Nacetylcysteine prophilaxis: meta-analysis. J Am Coll Cardiol Intv 2009; 2: 1116-1124

6. Nayak KR, Mehta HS, Price MJ, et al. A novel Technique for UltraLow Contrast Administration During Angiography or Intervention. Cathet Cardiovasc Interv 2010; 75: 1076-1083.
7. Anne G, Gruberg L, Huber A, et al. Traditional versus automated injection contrast system in diagnostic and percutaneous coronary interventional procedures: Comparison of the contrast volume delivered. J Invasive Cardiol 2004; 16: 360-362.

8. Khoukaz S, Kern MJ, Bitar SR, et al. Coronary angiography using $4 \mathrm{Fr}$ catheters with assisted automated injection: A randomized comparison to $6 \mathrm{Fr}$ manual technique and early ambulation. Cathet Cardiovasc Interv 2001; 52: 393-389.

9. Kaluski E, Moussa ID, Heuser RR, et al. Automated Contrast Injectors for Angiography : Devices, Methodology, and Safety. Cathet Cardiovas Interv 2009; 74: 459-464. 